\title{
Effect of Secondary and Micronutrients on Yield Forming Traits of Maize (Zea mays L.)
}

\author{
M. Ramanjineyulu ${ }^{1 *}$, M. Srinivasa Reddy ${ }^{1}$, P.V. Ramesh Babu ${ }^{1}$ and P. Kavitha ${ }^{2}$ \\ ${ }^{1}$ Department of Agronomy, ${ }^{2}$ Department of Soil Science and Agricultural Chemistry, \\ Agricultural College, Mahanandi-518502, Andhra Pradesh, India \\ *Corresponding author
}

\begin{abstract}
A B S T R A C T
Keywords

Maize, Secondary nutrients,

Micronutrients,

Yield attributes and Yield

Article Info

Accepted:

08 June 2018

Available Online:

10 July 2018

A field experiment was conducted at Agricultural College Farm, Mahanandi on sandy loam soils to know the response of maize to secondary and micronutrients with pioneer hybrid P3369. The experiment comprised of nine treatments consisting of recommended dose of fertilizer of NPK through soil application and foliar application of secondary and micronutrients at 20 days after sowing (DAS). Foliar application of micronutrients along with RDF recorded significantly highest grain yield of $4702 \mathrm{~kg} \mathrm{ha}^{-1}$ and stover yield of $7318 \mathrm{~kg} \mathrm{ha}^{-1}$ as compared RDF (3773 and $6430 \mathrm{~kg} \mathrm{ha}^{-1}$ of grain and stover yield, respectively). Yield attributes viz., number of cob plant ${ }^{-1}$, Number of rows $\operatorname{cob}^{-1}$, Number of grains row ${ }^{-1}$, cob length, cob girth, hundred grain weight were highest with the application of RDF + foliar application of $\mathrm{ZnSO}_{4}$ @ 0.1 per cent $\left(\mathrm{T}_{7}\right)$. The highest grain and stover yields was recorded with RDF + foliar application of micronutrient mixture @ 0.2 per cent which was on par with $\mathrm{RDF}+$ foliar application of $\mathrm{ZnSO}_{4} @ 0.1$ per cent $\left(\mathrm{T}_{7}\right)$ and superior over recommended dose of fertilizers and control. The treatment with RDF + foliar application of micronutrient mixture @ 0.2 per cent $\left(\mathrm{T}_{9}\right)$ recorded the highest gross returns, net returns and $\mathrm{B}: \mathrm{C}$ ratio.
\end{abstract}

\section{Introduction}

Maize (Zea mays L.) is the most important food grain crop next only to rice and wheat in World and India. It is one of the most important cereal crop in the world's agricultural economy, both as a food and feed crop and its value added products have a good export potential. Due to its versatile characteristics of suitability and adaptability to various Agro-climates, maize is gaining popularity among the Indian farmers. It is known as the "Queen of Cereals" due to its high yielding potential. Globally maize is cultivated in an area of 170.39 Million hectares with a production of 883.46 Million tonnes and productivity of 5.18 tonnes $\mathrm{ha}^{-1}$ (www.indiastat.com). In India, it is grown in an area of 8.55 Million hectares with a production of 21.73 Million tonnes and an average productivity of $2540 \mathrm{~kg} \mathrm{ha}{ }^{-1}$. In Andhra Pradesh, it is cultivated in an area of 9.72 lakh hectares with a production of 48.55 lakh tonnes and productivity of $4994 \mathrm{~kg} \mathrm{ha}^{-1}$. High yield of maize crops require large quantities of soil nutrients for its growth and 
development. Most of the farmers apply only fertilizers that supply major nutrients of $\mathrm{N}, \mathrm{P}$ and $\mathrm{K}$ and less attention is paid to secondary and micro nutrients which led to rapid depletion of secondary and micro nutrients necessity periodic or yearly supply of these nutrients. Although the requirement of secondary and micronutrients is small compared to macronutrients, nevertheless their deficiency can limit the crop growth and production. Furthermore, the adequate supply of these nutrients helps to increase the efficiency of the use of macronutrients. Therefore, field study was undertaken to optimize the nutrient management strategy for higher productivity of maize and evaluating the effects of secondary $(\mathrm{Ca}, \mathrm{Mg}$ and $\mathrm{S})$ and micronutrients ( $\mathrm{Fe}, \mathrm{Mn}, \mathrm{Zn}, \mathrm{Cu}, \mathrm{B}$ and $\mathrm{Mo}$ ) with recommended dose of nitrogen, phosphorus and potassium.

\section{Materials and Methods}

A field experiment was conducted on maize hybrid P3369, under irrigated conditions during kharif, 2015-16 on sandy loam soils of Agricultural College Farm, Mahanandi, Andhra Pradesh. The farm geographically situated at $15^{\circ} .51^{\prime} \mathrm{N}$ latitude and $78^{\circ} .61^{\prime} \mathrm{E}$ longitude, with an altitude of $233.48 \mathrm{~m}$ above the mean sea level in the scarce rainfall AgroClimatic Zone of Andhra Pradesh and according to Trolls classification, it falls under Semi-Arid Tropics (SAT). The average minimum and maximum monthly temperature, precipitation, relative humidity and wind speed during the crop period are shown in table.1 The soil of the experimental site was neutral $\mathrm{pH}$ (7.58), medium in organic carbon (0.46\%), N (287 kg ha $\left.{ }^{-1}\right), \mathrm{P}_{2} \mathrm{O}_{5}\left(149 \mathrm{~kg} \mathrm{ha}^{-1}\right)$ and high in $\mathrm{K}_{2} \mathrm{O}\left(742 \mathrm{~kg} \mathrm{ha}^{-1}\right)$. Exchangeable calcium, magnesium (10.41 and 7.22 $\mathrm{C}$ mol. $\left.\left(\mathrm{P}^{+}\right) \mathrm{kg}^{-1}\right)$ and available sulphur (13 $\left.\mathrm{kg} \mathrm{ha}^{-1}\right)$ were sufficient in availability whereas, micronutrients availability (Fe, $\mathrm{Mn}, \mathrm{Zn}, \mathrm{Cu}, \mathrm{B}$ and Mo) was more than their critical limits.
The experiment was laid out in a randomized block design having ten treatments and replicated thrice. The treatments consisting of $\mathrm{T}_{1}$ : Control, $\mathrm{T}_{2}$ : RDF: 250-60-60 kg N-P $\mathrm{O}_{5^{-}}$ $\mathrm{K}_{2} \mathrm{O} \mathrm{ha}{ }^{-1}, \mathrm{~T}_{3}$ : RDF + foliar application of one per cent $\mathrm{CaNO}_{3}, \mathrm{~T}_{4}$ : RDF+ foliar application of one per cent $\mathrm{MgNO}_{3}, \mathrm{~T}_{5}: \mathrm{RDF}+$ foliar application of one per cent sulphur, $\mathrm{T}_{6}$ : RDF + foliar application of one per cent each of $\mathrm{CaNO}_{3}, \mathrm{MgNO}_{3}$ and sulphur, $\mathrm{T}_{7}: \mathrm{RDF}+$ foliar application of $\mathrm{ZnSO}_{4} @ 0.2$ per cent, $\mathrm{T}_{8}$ : RDF + foliar application of one per cent each of $\mathrm{CaNO}_{3}, \quad \mathrm{MgNO}_{3}$ and sulphur + foliar application of $\mathrm{ZnSO}_{4} @ 0.2$ per cent and $\mathrm{T}_{9}$ : RDF + micronutrient mixture@0.2 per cent. Urea, di ammonium phosphate and muriate of potash were used for the supply of NPK and was applied as basal dose at the time of sowing, Whereas secondary nutrients and zinc was supplied through $\mathrm{CaNO}_{3}, \mathrm{MgNO}_{3}$, wettable sulphur and $\mathrm{ZnSO}_{4}$ respectively. Micronutrient mixture consists of Boron (B) $1.5 \%$, Copper $(\mathrm{Cu}) 0.5 \%$, Iron $(\mathrm{Fe}) 3.4 \%$, Manganese (Mn) 3.2\%, Molybdenum (Mo) $0.05 \%$ and Zinc (Zn) $4.2 \%$. Foliar spray of secondary and micronutrients was done at 20 DAS. The seeds were sown @ $20 \mathrm{~kg} \mathrm{ha}^{-1}$ with a spacing of $75 \times 15 \mathrm{~cm}$ on second fortnight 2015 and harvested at 23.11.2016 (118 days). The gross and net plot sizes were $15 \mathrm{~m} \mathrm{X} 4.5$ $\mathrm{m}$ and $12 \mathrm{~m} \mathrm{X} 3.9 \mathrm{~m}$, respectively. Carbofuran 3G granules@5 kg ha ${ }^{-1}$ were applied to control the stem borers. All the cultural practices were taken up as per the recommendations made by ANGRAU.

\section{Results and Discussion}

\section{Effect of secondary and micronutrients on yield attributes of maize}

The results indicated that different combinations of secondary and micronutrients had significant effect on yield attributes of maize (Table 2). The maximum values of yield attributes like number of rows $\mathrm{cob}^{-1}$ (16.97), number of grains per row (36.99), cob length 
(19.86) were recorded with the treatment $\mathrm{T}_{7}$ (RDF + foliar application of $\mathrm{ZnSO}_{4} @ 0.1$ per cent) which was comparable with $\mathrm{T}_{9}(\mathrm{RDF}+$ Foliar application of 0.1 per cent micronutrient mixture). However, highest hundred grain weight was recorded with foliar application of one per cent each of $\mathrm{CaNO}_{3}$, $\mathrm{MgNO}_{3}$ and sulphur $+\mathrm{ZnSO}_{4} @ 0.1$ per cent with $\operatorname{RDF}\left(\mathrm{T}_{8}\right)$ which was on par with $\mathrm{T}_{9}$ (RDF + Foliar application of 0.1 per cent micronutrient mixture). Data on number of cobs per plant and cob girth was not significantly influenced by secondary and micronutrient

In maize, the yield attributes viz. number of grains rows $^{-1}$, number of rows $\mathrm{cob}^{-1}$, cob length, cob girth and 100-grain weight was influenced by NPK and Zn. A marked increase of these yield attributes were nearly found with $\mathrm{T}_{7}\left(\mathrm{RDF}+\right.$ foliar application of $\mathrm{ZnSO}_{4} @$ 0.1 per cent). NPK and $\mathrm{Zn}$ are essential nutrients required for the promotion of the meristematic and physiological activities such as leaf spread, root development, plant dry matter production, greater availability of metabolites and nutrients leading to efficient absorption and translocation of water and nutrients and interception of solar radiation. Zinc has control over the synthesis and accumulation of starch in kernals (Guliev 1992). The functional role of $\mathrm{Zn}$ includes auxins metabolism, nitrogen metabolism, influence on the activities of enzymes, cytochrome synthesis and stabilization of ribosomal fractions (Tisdale et al., 1997). Nitrogen in the presence of sufficient zinc shows its optimal performance and promotes higher photosynthetic activities leading to the production of enough assimilates for subsequent translocation to various sinks and there by leading to production of higher sink components like number of cobs plant ${ }^{-1}$, cob length, cob girth, number of rows $\mathrm{cob}^{-1}$, number of grains row $^{-1}$ and 100-grain weight. The positive yield forming effect of foliar application of zinc (Wronska et al., 2007; Potrycki 2011). The results are in conformity with the findings of Aruna et al (2006), Duraisami et al., (2007), Parasuraman et al., (2008), Meena et al., 2013) and Khan et al., (2014).

Among the secondary nutrients, $\mathrm{RDF}+$ foliar application of one per cent $\mathrm{MgNO}_{3}\left(\mathrm{~T}_{4}\right)$ had shown profound effect with respect to yield attributes and yield but superior over RDF+ foliar application of one per cent $\mathrm{CaNO}_{3}\left(\mathrm{~T}_{3}\right)$ and $\mathrm{RDF}+$ foliar application of one per cent sulphur $\left(\mathrm{T}_{5}\right)$. This increment on yield attributes might be due to presence of magnesium, as grain number are direct index of pollen viability and where magnesium is proved to increase the fruit set and pollen viability, and significantly affect the pollen formation (Mahgoub et al.,2010 and Siam et al.2008). This element will also participate in the transportation of carbohydrates to the sink organs (Barlog and Frckowiak-Pawalak 2008).

Table.1 Average maximum and minimum monthly temperature, rainfall, relative humidity and wind speed during kharif - 2015

\begin{tabular}{|c|c|c|c|c|c|}
\hline month & $\begin{array}{c}\text { Maximum } \\
\left.\text { temperature } \mathbf{(}^{\mathbf{0}} \mathbf{c}\right)\end{array}$ & $\begin{array}{c}\text { Minimum } \\
\left.\text { temperature } \mathbf{(}^{\mathbf{0}} \mathbf{c}\right)\end{array}$ & Rainfall (mm) & $\begin{array}{c}\text { Relative } \\
\text { humidity } \mathbf{( \% )}\end{array}$ & $\begin{array}{c}\text { Wind speed } \\
\left(\mathbf{k m ~ h r}^{\mathbf{- 1}}\right)\end{array}$ \\
\hline July & 33.7 & 23.7 & 2.12 & 72.55 & 4.31 \\
\hline August & 34.4 & 24.1 & 2.38 & 73.76 & 4.34 \\
\hline September & 32.6 & 23.6 & 8.14 & 76.13 & 4.02 \\
\hline October & 34.1 & 22.0 & 1.72 & 70.18 & 2.21 \\
\hline November & 31.4 & 20.3 & 1.67 & 70.65 & 3.05 \\
\hline
\end{tabular}


Table.2 Effect of secondary and micronutrients on yield attributes and yield of maize

\begin{tabular}{|c|c|c|c|c|c|c|}
\hline Treatments & $\begin{array}{l}\text { Number of cobs } \\
\text { plant }^{-1}\end{array}$ & $\begin{array}{l}\text { Number of rows } \\
\operatorname{cob}^{-1}\end{array}$ & $\begin{array}{l}\text { Number of } \\
\text { grains row }^{-1}\end{array}$ & Cob length $(\mathrm{cm})$ & $\begin{array}{l}\text { Cob girth } \\
(\mathrm{cm})\end{array}$ & $\begin{array}{l}\text { 100-Grain } \\
\text { weight }(\mathrm{g})\end{array}$ \\
\hline $\mathrm{T}_{1}$ : Control & 1.00 & 12.98 & 19.99 & 11.99 & 11.66 & 21.76 \\
\hline $\mathrm{T}_{2}: \mathbf{2 0 - 4 0 - 5 0} \mathrm{kg} \mathrm{N}-\mathrm{P}_{2} \mathrm{O}_{5}-\mathrm{K}_{2} \mathrm{O}$ ha $^{-1}$ & 1.00 & 14.11 & 32.14 & 17.13 & 14.25 & 26.30 \\
\hline $\mathrm{T}_{3}: \mathrm{T}_{2}+$ foliar application of $1 \% \mathrm{CaNO}_{3}$ & 1.00 & 15.12 & 33.85 & 18.14 & 14.81 & 27.45 \\
\hline $\mathrm{T}_{4}: \mathrm{T}_{2}+$ foliar application of $1 \% \mathrm{MgNO}_{3}$ & 1.00 & 15.66 & 34.95 & 17.46 & 13.89 & 28.67 \\
\hline $\mathrm{T}_{5}: \mathbf{T}_{\mathbf{2}}+$ foliar application of $1 \%$ sulphur & 1.06 & 15.53 & 33.17 & 19.04 & 14.24 & 28.46 \\
\hline $\begin{array}{l}\mathrm{T}_{6}: \text { RDF + foliar application of one per cent each of } \\
\mathrm{CaNO}_{3} \mathrm{MgNO}_{3} \text { and sulphur }\end{array}$ & 1.00 & 15.87 & 35.11 & 19.09 & 14.69 & 29.47 \\
\hline $\mathrm{T}_{7}: \mathrm{T}_{2}+$ foliar application of $\mathbf{Z n S O}_{4} @ \mathbf{0 . 2 \%}$ & 1.06 & 16.97 & 36.99 & 19.86 & 14.72 & 29.70 \\
\hline $\mathrm{T}_{8}: \mathrm{T}_{6}+$ foliar application of $\mathrm{ZnSO}_{4} @ \mathbf{0 . 2 \%}$ & 1.00 & 16.40 & 34.03 & 19.14 & 14.61 & 31.26 \\
\hline $\mathrm{T}_{9}: \mathrm{T}_{2}+$ micronutrient mixture @ $0.2 \%$ & 1.00 & 15.99 & 36.09 & 18.27 & 14.21 & 30.53 \\
\hline SEm \pm & 0.03 & 0.13 & 0.30 & 0.19 & 1.43 & 0.23 \\
\hline $\mathrm{CD}(\mathrm{P}=0.05)$ & N.S & 0.39 & 0.92 & 0.59 & N.S. & 0.71 \\
\hline
\end{tabular}


Table.3 Effect of secondary and micronutrients on Cost of cultivation, gross returns, net returns $\left(₹ \mathrm{ha}^{-1}\right.$ ) and $\mathrm{B}$ : C ratio of maize

\begin{tabular}{|c|c|c|c|c|}
\hline Treatments & $\begin{array}{c}\text { Cost of } \\
\text { cultivation }\left(₹ \mathrm{ha}^{-1}\right)\end{array}$ & $\begin{array}{l}\text { Gross returns } \\
\left(₹ \mathrm{ha}^{-1}\right)\end{array}$ & $\begin{array}{l}\text { Net returns } \\
\left(₹ \mathrm{ha}^{-1}\right)\end{array}$ & $\mathrm{B}: \mathrm{C}$ ratio \\
\hline$T_{1}$ : Control & 16270 & 34667 & 18397 & 1.13 \\
\hline $\mathrm{T}_{2}: 20-40-50 \mathrm{~kg} \mathrm{~N}-\mathrm{P}_{2} \mathrm{O}_{5}-\mathrm{K}_{2} \mathrm{O} \mathrm{ha}{ }^{-1}$ & 21771 & 49059 & 27288 & 1.25 \\
\hline $\mathrm{T}_{3}: \mathrm{T}_{2}+$ foliar application of $1 \% \mathrm{CaNO}_{3}$ & 22421 & 55081 & 32695 & 1.45 \\
\hline $\mathrm{T}_{4}: \mathrm{T}_{2}+$ foliar application of $1 \% \mathrm{MgNO}_{3}$ & 22371 & 55809 & 33436 & 1.49 \\
\hline$T_{5}: T_{2}+$ foliar application of $1 \%$ sulphur & 21871 & 54454 & 32583 & 1.49 \\
\hline $\begin{array}{c}\mathrm{T}_{6}: \mathrm{RDF}+\text { foliar application of one per cent } \\
\text { each of } \mathrm{CaNO}_{3}, \mathrm{MgNO}_{3} \text { and sulphur }\end{array}$ & 24121 & 54696 & 30575 & 1.38 \\
\hline $\mathrm{T}_{7}: \mathrm{T}_{2}+$ foliar application of $\mathrm{ZnSO}_{4} @ 0.2 \%$ & 22171 & 59098 & 36927 & 1.59 \\
\hline $\mathrm{T}_{8}: \mathrm{T}_{6}+$ foliar application of $\mathrm{ZnSO}_{4} @ 0.2 \%$ & 24521 & 54678 & 30157 & 1.22 \\
\hline$T_{9}: T_{2}+$ micronutrient mixture @ $0.2 \%$ & 22771 & 61109 & 38338 & 1.68 \\
\hline S.Em \pm & --- & 611 & 607 & 0.02 \\
\hline
\end{tabular}

Fig.1 Effect of secondary and micronutrients on yield $\left(\mathrm{kg} \mathrm{ha}^{-1}\right)$ of maize

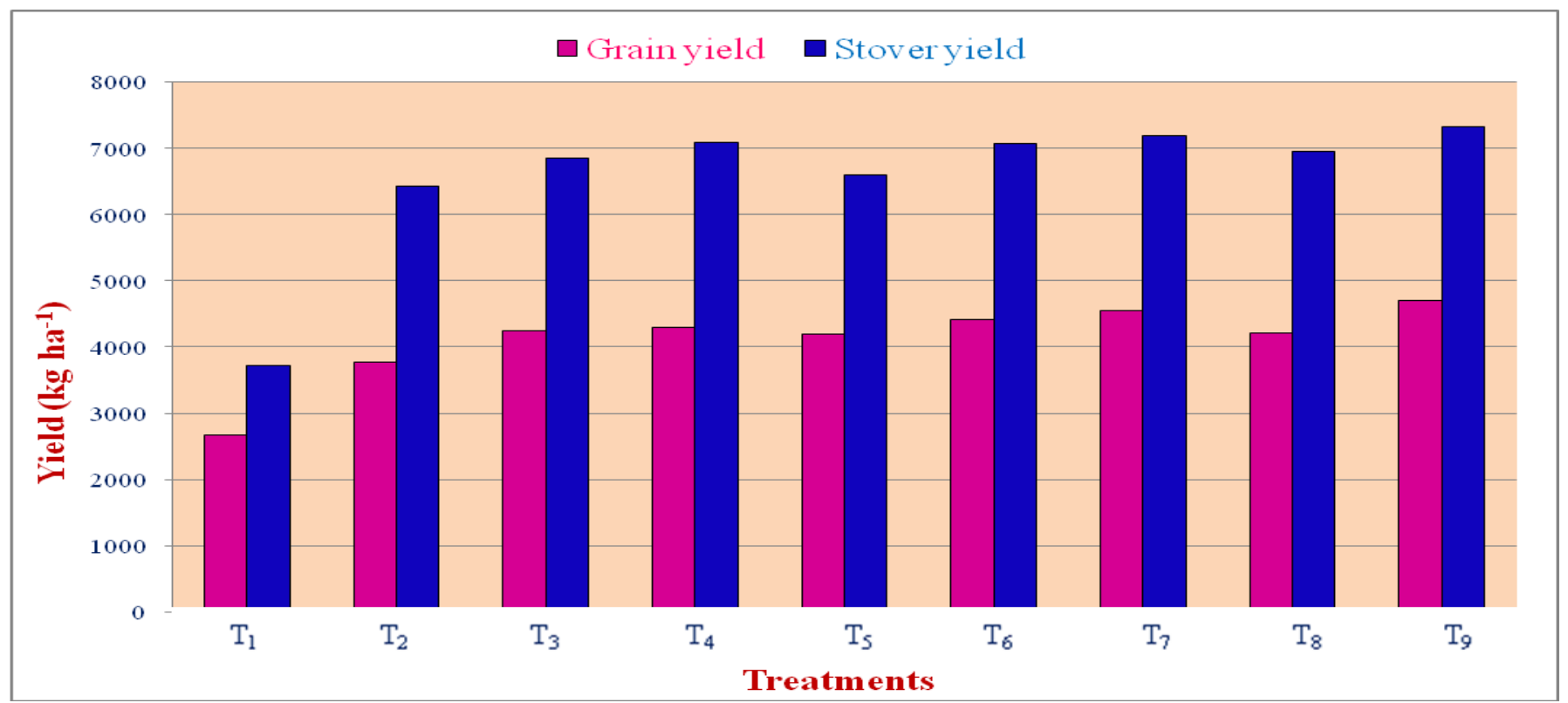


Effect of secondary and micronutrient on grain and stover yield

Data regarding the grain yield and stover yield in Fig.1 showed the treatment with foliar application of 0.2 per cent micronutrient mixture with RDF $\left(\mathrm{T}_{9}\right)$ recorded highest grain $\left(4702 \mathrm{~kg} \mathrm{ha}^{-1}\right)$ and stover yields $(7318 \mathrm{~kg}$ $\mathrm{ha}^{-1}$ ) which was on par with $\mathrm{T}_{7}(\mathrm{RDF}+$ foliar application of 0.1 per cent $\mathrm{ZnSO}_{4}$ ), while the lowest grain and stover yields were recorded with $\mathrm{T}_{1}$ (Control). This increase may be due to the additional availability of micronutrients as foliar application which had beneficial effect on physiological processes, plant metabolism, growth etc. which will directly put forth for higher grain yield. Synergetic role of micronutrients in improving plant growth and other biochemical and physiological activities was given by (Kassab et. al, 2004 and Zeiden et. al, 2010). The nutrients also enhance the carbohydrates supply to kernels by diverting assimilates from sources, increasing yield components like cob length, cob girth, number of rows $\mathrm{cob}^{-1}$, number of grains row ${ }^{-1}$ and test weight, which have direct influence on grain yield. Similar results were reported by Aruna et al., (2006), Ghaffari et al., (2011) and Salem et al., (2013).

\section{Economics}

The successful adoption of nutrient management practice is finally determined by the net financial gain (Table.3). The best nutrient management practice was foliar application of 0.2 per cent micronutrient mixture with $\mathrm{RDF}\left(\mathrm{T}_{9}\right)$ attaining 38,338 net field benefits with $\mathrm{B}: \mathrm{C}$ ratio 1.68 which was comparable with foliar application of 0.1 per cent $\mathrm{ZnSO}_{4}+\operatorname{RDF}\left(\mathrm{T}_{7}\right)(36,927)$ and rest of treatments net benefits were low to recommend to farmer.

It could be concluded from the findings that the among the secondary nutrients, foliar application of magnesium was beneficial in improving yield parameters and yield of maize. With regard to micronutrients, zinc had shown profound effect on growth and yield parameters compared to other micronutrients. So it can be recommended that foliar application of micronutrient mixture along with recommended fertilizer level is feasible for enhancing yield and profitability of maize hybrid pioneer-3369.

\section{References}

Aruna, M., Veeraraghavaiah, $\mathrm{R}$ and Chandrasekhar, K. (2006). Productivity and quality of maize (Zea mays L) as affected by foliar application of $\mathrm{N}$ and $\mathrm{Zn}$ at flowering. The Andhra Agricultural Journal. 53(1\&2): 17-19.

Barlog P. and Frckowiak-Pawlak K., "Effect of mineral fertilization on yield of maize cultivars differing in maturity scale," Acta Sci. Pol. Agricultura, Vol. 7, No. 5, 2008, pp. 5-17.

Duraisami, V.P., Chitdeshwari, T., K.S. Subramanian, K.S And R.Rajeswari 2007. Effect of micronutrients and sulphur on yield and nutrient uptake by Maize in an alfisol. Madras Agricultural Journal. 94(7-12): 283288.

Ghaffari, A., Asghar Ali, Muhammad Tahir, Muhammad Waseem, Muhammad Ayub, Asif Iqbal and Atta Ullah Mohsin. (2011). Influence of integrated nutrients on growth, yield and quality of maize (Zea mays L.). American Journal of Plant Sciences. 2- $63-69$.

Guliev, N., Bairamov, S., Aliew, D. 1992. Functional organization of carbonic anhydrase in higher plants. Sovient Plant Physiology. 39, 537-544.

Kassab, O.M., H.A.E. Zeing and M.M. Ibrahim, 2004. Effect of water deficit and micronutrients foliar application 
on the productivity of wheat plants. Minufiya J. Agric. Res., 29: 925-932

Khan, H.Z., Abdullah, Amin, M., Akbar, N., Saleem, M.F and Iqbal, A. 2014. Impact of zinc and manganese application to increase productivity of autumn planted maize (Zea mays L.).Cercetari Agronomice in Moldova 4(160):10.1515.

Mahgoub M. H., El-QuesniFatma, E. M. and M.Kandil M., "Response of Vegetative Growth and ChemicalConstituents of Schefflera Arboricola L. Plant to FoliarApplication of Inorganic Fertilizer (Grow-More) andAmmonium Nitrate at Nubaria," Ozean Journal of AppliedScience, Vol. 3, 2010, pp. 177-184.

Meena, S, K, Mundra, S.L and Singh, P. 2013 Response of maize (Zea mays) to nitrogen and zinc fertilization Indian Journal of Agronomy. 58(1): 127-128.

Parasuraman, P., Prakash, R and Chandrasekaran, B. 2008. Response of hybrid maize (Zea mays L.) to soil and foliar application of nutrients. Madras Agricultural Journal. 95 (1 -6): 202 204.

Potarzycki, J., 2011. Effect of magnesium or zinc supplementation at the background of nitrogen rate on nitrogen management by maize canopy cultivated in monoculture. Plant Soil Environ. 57: 19-25.

Salem hythum, M and Nasser kh El Gizawy, B. 2012 Importance of micronutrients and its application methods for improving maize (Zea mays L.) yield grown in clayey soil. American Eurasian Journal of Agriculture and Environment science 12(7): 954-959.

Siam H. S., Abd-El-Kader. M. G. and El-Alia H. I., "Yield and yield components of maize as affected by different sources and application rates of nitrogen fertilizer," Research Journal of Agriculture and Biological Sciences, Vol. 4, No. 5, 2008, pp. 399-412.

Tisdale, I. S., I. W. Nelson, D. J. Beaton and I. J. Havlin. 1997. Soil Fertility and Fertilizers. 5th ed. Prentice Hall of India.

Wronska, M., Grzebisz, W., Potarzycki, P., Gaj R. 2007: Maize response to nitrogen and zinc fertilization. Grain yield and elements of yield structure. Fragmenta Agronomica, 22: 390-399.

Zeidan, M.S., M.F. Mohamed and H.A. Hamouda, 2010. Effect of foliar fertilization of $\mathrm{Fe}, \mathrm{Mn}$ and $\mathrm{Zn}$ on Statistical wheat yield and quality in low sandy soils fertility. World Journal of Agricultural Sciences, nd 6 (6): 696-699.

\section{How to cite this article:}

Ramanjineyulu, M., M. Srinivasa Reddy, P.V. Ramesh Babu and Kavitha, P. 2018. Effect of Secondary and Micronutrients on Yield Forming Traits of Maize (Zea mays L.). Int.J.Curr.Microbiol.App.Sci. 7(07): 1125-1131. doi: https://doi.org/10.20546/ijcmas.2018.707.136 